\title{
Proqram Təminatında Lisenziyalaşdırma Problemləri
}

\author{
İradə Oləkbərova ${ }^{1}$, Zülfiyyə Hənifəyeva ${ }^{2}$ \\ 1,2 İnformasiya Texnologiyaları İnstitutu, Azərbaycan, Bakı \\ lairada.09@gmail.com, ${ }^{2}$ zulfiyyehenifeyeva@gmail.com
}

\begin{abstract}
Xülasə- Məqalədə proqram təminatları lisenziyaları ilə bağlı bəzi problemlər araşdırılmışdır. Proqram təminatından əldə olunan gəlirin özünü doğrultması üçün əsas şərtlər müəyyənləşdirilmişdir.
\end{abstract}

Açar sözlor-proqram tominatı bazarı, proqram tominatı mühondisi, azad lisenziya, icazosiz istifado

\section{GİRIS}

Bulud texnologiyaları da daxil olmaqla informasiya kommunikasiya texnologiyalarının (İKT) sürətli inkişafı İnternet resurslarının artmasına və proqram təminatı (PT) mühəndislərinin və istifadəçilərinin fəallığına əhəmiyyətli təsir göstərməkdədir [1]. Buludlar vasitəsilə təqdim olunan proqramların imkanları və funksionallıqları sifarişçilərin tələbinə uyğun olaraq dəyişir. Şəbəkəyə qoşulmuş mobil qurğularla işləyən istifadəçiləri şəbəkə üçün nəzərdə tutulan proqramın əsas şəbəkəyə necə qoşulması deyil, proqramın əlyetərliyi, q1vraqlığı və təhlükəsizliyi ilə bağlı məsələlər maraqlandırır. Onlara PT bir xidmət kimi təqdim olunur və əksər hallarda bu xidmətə görə müəyyən ödəniş edilir. PT ilə əlaqədar ödənişlər və razılaşmalar müvafiq lisenziya əsasında həyata keçirilir [2].

PT dedikdə müəyyən elektron qurgularda istifadə üçün nəzərdə tutulmuş proqram məhsulları və onların istismarında lazım olan sənədlər, qaydalar nəzərdə tutulur [3]. PT üçün lisenziya müəllif hüquqları ilə qorunan proqram məhsullarının istifadəsi və yayılmasını müəyyən edən hüquqi alətdir. $\mathrm{O}$, istifadəçiyə bu proqramın sürətindən istifadə hüququ verir. Müəllif hüququ ilə qorunan proqramlardan lisenziyasız istifadə cinayət hesab edilir [4]. Tədqiqatda əsas məqsəd proqram istifadəçilərinin lisenziyalı proqramlara olan tələblərini müəyyən etmək və bu sahədə mövcud problemləri araşdırmaqdır.

\section{PROQRAM TOMINATI BAZARI}

Müasir dövrdə PT bazarı fundamental dəyişikliklərə məruz qalır. Şəbəkə vasitəsilə yüklənmiş PT ağıllı İnternet avadanlıqlarına xidmət kimi təqdim olunur və hazırda PT əldə etmək üçün bulud xidmətlərindən geniş istifadə olunur. Lakin istifadəçiyə təqdim olunan PT-nın bütün tələblərə nə dərəcədə cavab verməsi müəyyən araşdırma tələb edir. Belə ki, PT-nın səmərəli işi, etibarlılığ qiyməti istifadəçini qane etməlidir. Oks halda PT mühəndisi ilə sifarişçi arasında müəyyən anlaşılmazlıqlar yarana bilər. Təyinatına görə PT üç kateqoriyaya bölünürlər:

1. sifarişlə yaradılan;

2. böyük şirkətlər və təşkilatlar üçün nəzərdə tutulan;

3. kütləvi istifadə üçün nəzərdə tutulan.
Araşdırmalardan məlum olmuşdur ki, PT bazarında uzun müddət fəaliyyət göstərən proqramçılar və mütəxəssislər ənənəvi modellərlə işləməyə üstünlük versələr də, genişlənən bulud texnologiyaları və Big Data problemləri PT mühəndislərindən müasir tələblərə uyğun proqram məhsulları tələb edir [2,5].

PT bazarı informasiya texnologiyları (ITT) avadanlıqları bazarı və konsaldinq xidmətləri ilə birgə İT bazarının seqmentlərini təşkil edir. PT bazarı özü də üç sektora bölünür: tətbiqi PT bazarı, proqramların işlənmə vasitələri bazarı, sistem və infrastruktur PT bazarı (şəkil 1).

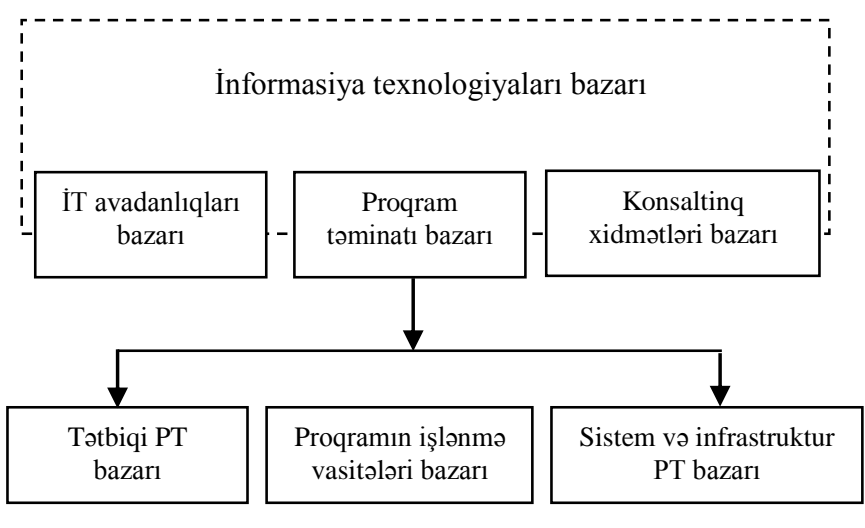

Şəkil 1. PT bazarı sektorları

Hər bir sektor da müxtəlif seqmentlərə bölünür. Məsələn, tətbiqi PT bazarı öz növbəsində istifadəçi proqram, qrup şəklində işin təşkili vasitələri, kontentlərlə işləmək üçün əlavələr, təşkilatın resurslarının idarə olunması üçün PT, istehsal və proseslərin idarəsi üçün PT, mühəndis PT, müştəri və tərəfdaşlarla münasibətlərin idarə olunması sistemləri və s. təklif edir. IKKT-nin dinamik şəkildə dəyişdiyi bir zamanda PTnin işlənilməsinə ayrılan xərclərin çox hissəsi proqram kodunun yazılmasına deyil, tələblərin idarə edilməsi, proqram layihələrinin menecmenti, onların sınaqdan keçirilməsi, PTnın mövcud infrastruktura inteqrasiya edilməsi və $\mathrm{s}$. məsələlərə xərclənir. Bu səbəbdən PT-nın hazırlanmasında böyük xərc tələb edilirsə, onun PT bazarında rəqabətə davamlılı̆̆1 problemi aktuallaşır [6].

Daha sərfəli qiymətlə PT əldə etmək üçün istifadəçinin qarşısında duran əsas vəzifələr aşağıdakılardır:

- lisenziyalı proqramı düzgün seçməyi bacarmaq;

- lisenziyalı proqram üçün çəkilən xərcləri minimuma endirmək;

- yeni lisenziyalı proqrama keçid üçün şərtləri öyrənmək; 
- lisenziyalı proqramı düzgün yükləmək və istifadə etmək bacarığına malik olmaq.

Bir çox PT mühəndisləri üçün proqram platformalarından istifadə etməklə gəlir əldə etmək intellektual mülkiyyətin satışından əldə olunan gəlir hesab edilir. Yuxarıda deyildiyi kimi, PT bazarında lisenziyalı proqramı düzgün seçmək, yükləmək və istifadə etmək bacarığına malik mütəxəssislər yüksək qiymətləndirilir.

\section{PROQRAM TӘMINATINDA LISSENZIYA}

Lisenziyaya görə PT-lar 2 qrupa bölünür: azad istifadə üçün və azad olmayan. PT mühəndislərinin çoxunu azad olmayan PT-dan qanunsuz istifadə, başqa sözlə, sui-istifadə, oğurluq və ya piratçılıq, lisenziya müqavilələrinin qeyri-şüuri pozulması halları narahat edir. Proqram istifadəçiləri isə azad lisenziyalı PT və ya sərfəli lisenziya qaydalarına üstünlük verirlər.

\section{A. Azad olmayan PT üçün lisenziya}

İstifadəçi azad olmayan PT-nı lisenziya ilə birgə əldə edir. Lisenziya istifadəçiyə PT-dan müəyyən olunmuş şərtlər çərçivəsində istifadə etməyə icazə verir. Lakin lisenziyada göstərilən şərtlər bir çox hallarda PT ilə əlaqədar istifadəçinin imkanlarını məhdudlaşdıra bilər. Belə ki, lisenziya razılaşmaları proqramın icazəsiz dəyişdirilməsinin və yayılmasının qarşısını alır. Nəzərə almaq lazımdır ki, son mərhələdə sifariş olunan proqramın sahibi istifadəçi olsa da, bütün müəllif hüquqları əvvəlki kimi, PT mühəndisinə məxsus olur və lisenziya PT mühəndisi və istifadəçinin üzərinə düşən tələbləri dəqiqləşdirir. $\mathrm{Bu}$ tip proqramlar "Commercial software" lisenziyasına malikdirlər. Adından da göründüyü kimi bu PT-lər komersiya xarakterlidir, gəlir əldə etmək məqsədi ilə yaradılmışdır və yalnız tam ödəniş həyata keçirildikdən sonra onları kompüterə yükləmək və istifadə etmək mümkündür [7].

\section{B. Azad PT üçün lisenziya}

Azad lisenziyaya (free software) malik PT-nın sərbəst istifadəsinə və yayılmasına icazə verilir və onların ilkin kodu açıq olur. Açıq kodlu PT-nin kodunda dəyişiklik etməklə onu istifadəçinin tələbinə uyğunlaşdırmaq mümkündür. Lakin bu zaman da PT-da müəlliflik hüquqları qorunur. Məsələn, bir çox hallarda açıq kodlu proqramların kommersiya məqsədilə istifadəsinə icazə verilmir. Bu halda proqramda edilən bütün dəyişikliklər ilkin kodla qeyd edilməlidir.

Ogər kommersiya lisenziyasına malik PT üçün ödəniş edilmişdirsə o, bir çox hallarda azad lisenziyalı PT kimi təqdim oluna bilər. Azad proqram məhsulları adətən "GNU General Public License" (GNU GPL), "World Wide Web Consortium" (W3C), "Apache Software License", "Mozilla Public License", "Freeware", "Adware", "Postcardware" və s. kimi lisenziyalardan birinə malik olmalıdırlar [8]. Məsələn, GNU GPL lisenziyasına malik PT üçün verilən əsas icazələr aşağıdakılardır [9]:

- proqramdan istənilən məqsəd üçün istifadə oluna bilər;

- proqramın araşdırılması və istifadəçinin tələbatına uyğun şəkildə dəyişdirilməsinə icazə verilir;
- proqramın sürətinin azad yayılması mümkündür.

Azad lisenziyalı PT qeyri-kommersiya və ya tamamilə pulsuz PT demək deyildir. Belə PT kommersiya məqsədi ilə də istifadə oluna bilər, lakin o zaman bir şox hallarda ödəniş etmək tələb olunur. Oksər azad lisenziyalı PT-lər müəlliflik hüquqlarına əsaslanır və bu halda onların yayılmasına və dəyişdirilməsinə müəllif tərəfindən məhdudiyyətlər qoyula bilər [9].

Azad lisenziyalı PT ilə açıq PT (open software) fərqli anlayışlardır, baxmayaraq ki, hər iki anlayışda oxşar xüsusiyyətlər çoxdur. Ogər azad lisenziyada PT-nın istifadə müddətinə və imkanlarına hər hans1 bir məhdudiyyət qoyulmursa, açıq proqramlarda belə məhdudiyyətlər ola bilər. Odur ki, bəzi açıq lisenziyalı proqramlar şərti-pulsuz PT siyahısına daxildirlər.

\section{C. Şərti-pulsuz PT üçün lisenziya}

Şərti-pulsuz (shareware) PT-nın əsas üstün cəhəti ondan ibarətdir ki, PT üçün ödəniş etməzdən öncə ondan müəyyən müddətə pulsuz istifadəyə iczə verlir. $\mathrm{Bu}$ müddət ərzində istifadəçi proqramı testdən keçirir, imkanları ilə tanış olur. Yalnız bu proqramın həqiqətən də onu qane edə biləcəyindən əmin olandan sonra istifadəçi PT-nin orijinalını əldə etmək üçün ödəniş edir. Şərti-pulsuz PT üçün lisenziyalalara misal olaraq Shareware, Trialware, Demoware göstərmək olar [10].

Məsələn, nümayiş üçün nəzərdə tutulmuş demo (demoware) lisenziyalı PT müəyyən müddət pulsuz təqdim olunur və əsas versiya ilə müqayisədə onun funksionallığına məhdudiyyətlər qoyulur. Oslində demo lisenziyalı proqram ödənişli PT-nın nüsxəsidir və istifadəçiyə orjinal proqram haqqında təsəvvür yaratmaq üçün və prqoramda işləmək vərdişi əldə etmək üçün pulsuz təklif edilir. Test müddəti qurtardıqdan sonra istifadəçiyə açıq PT-nı bütün fuksiyaları da daxil olmaqla pulla əldə etmək təklif olunur. Trialware da şərti-pulsuz PT siyahısına daxildir. Funksionallığında məhdudiyyət yoxdur. Yalnız bir-neçə gün pulsuz istifadəyə icazə verilir. Deyilənləri nəzərə alaraq şərti-pulsuz proqramların çatışmazlıqlarını aşağıdakı kimi təsnifatlandırmaq olar:

- proqram məhdud zaman çərçivəsində işləyir;

- proqramın imkanları süni şəkildə məhdudlaşdırılır;

- proqram yalnız bir və ya bir-neçə dəfə yüklənə bilər;

- proqramın emal etdiyi faylların sayı və ya informasiyanın həcmi məhduddur.

Azad, açıq və şərti-pulsuz PT istehsalı əsasən piratçılığın, proqram oğurluğunun qarşısının alınması, vətəndaşların intellektual səviyyəsinin yüksəldilməsi, dövlətin informasiya məkanının gücləndirilməsi üçün nəzərdə tutulur.

\section{PROQRAM TӘMINATINDA LISENZIYA İLӘ BAĞLI PROBLEMLӘR}

PT sahəsi üzrə lisenziya siyasətində ciddi qaydalar keçən əsrin sonlarında tətbiq olunmağa başladı. Onlarla ölkə, on minlərlə şirkətlər və yüz minlərlə vətəndaş PT-da icazəsiz istifadəyə görə "cinayətkar" və "borclular" siyahısına daxil 
edildilər. Bu gün demək olar ki, korporativ müştərilərin yarısı lisenziya müqavilələrinin ən azı birini yerinə yetirmir [11].

PT satışında əsas şərt qarşılıqlı etibarlı münasibətlərdir, amma ənənəvi proqram lisenziyalaşdırılması modeli bu münasibətlərin inkişafina müəyyən maneələr yaradır. Nəzərə almaq lazımdır ki, lisenziya yalnız PT mühəndislərinin hüquqlarını təmin edən mexanizm deyil, həm də müştərinin şübhələrinin və narahatçılığının aradan qaldırılması üçün vasitədir. PT mühəndisləri proqram üçün böyük vəsait tələb edirlərsə, onlar hesab edirlər ki, bu yolla istifadəçilər proqramın etibarlılığına və keyfiyyətinə əminlik əldə etməlidirlər. PT istifadəçiləri isə əksinə, hesab edirlər ki, PTnin lisenziyalaşdırılması və böyük vəsait tələbi informasiya ilə işləyən vətəndaşların hüquqlarını pozur, informasiya comiyyətinin inkişafina mane olur $[9,11]$.

PT-dan gəlir əldə edilməsi ilə bağlı problemləri daha yaxşı anlamaq üçün Gemalto şirkəti tərəfindən keçirilən araşdırma ilə tanış olmaq yetərlidir. Şirkət dünyanın müxtəlif ölkələrində yerləşən təşkilatlarda sorğu keçirmişdir. $\mathrm{Bu}$ sorğuya Avstraliya, Almaniya, Fransa, Yaponiya, İsveçrə, Böyük Britaniya və ABŞ şirkətlərindən 500-dən çox işçi, həmçinin ən az1 hərəsindən 10 nəfər olmaqla 180 müxtəlif şirkətin proqramçıları cəlb olunmuşlar. Sorğu nəticəsində məlum olmuşdur ki, əməkdaşların 83\%-i PT paketlərinin kifayət qədər çevik və sadə olmalarını arzulayırlar. Onlar həmçinin, hesab edirlər ki, PT müxtəlif təyinatlı informasiya vasitələri üçün əlyetərli olmalıdır [12].

Sorğularda iştirak edənlərin yalnız 10\%-i PT lisenziyalaşdırılması ilə bağlı çətinliklərin olmadığını bildirdilər. 90\%-i isə, PT-nin biznes üçün uyğun olmamas1, proqramın istifadəsində çətinliklər, uzun aktivləşdirmə vaxtı və lisenziya açarının itirilməsi ilə bağlı narazılıqlarını bildirdilər [12].

Ümumi şəkildə PT üçün lisenziyaların verilməsi ilə proqramdan istifadə imkanları arasında yəni, tələb və təklif arasında ziddiyyət mövcuddur:

1. PT mühəndislərinin əksəriyyəti yaratdıqları proqramların etibarlı olmasını iddia edirlər və PT-dən əldə olunan gəlirlərin özünü doğrultması məqsədi ilə təhlükəsizlik alətlərindən və etibarlı proqramlardan istifadə etməyə üstünlük verir, lisenziya siyasətinin daha da ciddiləşdirilməsini tələb edirlər;

2. PT istifadəçiləri proqram lisenziyalarına qoyulmuş məhdudiyyətlərin aradan qalxmasını və ödənişin yeni modellərinin tətbiq edilməsini tələb edirlər.

Nəzərə almaq lazımdır ki, bu məsələlər müəyyən qədər hüquqi idarəetməyə (entitlement managment) aiddir. Tələblərin $100 \%$ yerinə yetirilməməsinin obyektiv və subyektiv səbəbləri var ki, bunlara da istifadə olunan proqram platformasının imkanlarından başlayaraq proqramçının bilik səviyyəsinə kimi bütün məsələlər aiddir.

\section{MÜASIR PROQRAM TOMINATLARI ÜÇÜN TOLOBLOR}

PT bazarında əsas tələblərdən biri sifarişçinin bütün tələblərinə uyğun, az xərc tələb edən proqram məhsulunun hazırlanmasıdır. Gartner jurnalının statistikasına görə 2016-cı ildə təxminən 6,4 milyard "məhsulun" (PT və digər informasiya resurslarının) İnternet şəbəkəsinə qoşulacağ1 bildirilmişdir ki, bu da 2015-ci ildə olan nəticələrdən 30\%-dən çox olduğunu göstərir. Analitiklər 2019-cu ildə İT ilə əlaqədar çəkilən xərclərin $\$ 2,8$ trln. olacağını proqnozlaşdırırlar. İT sahəsində ən sürətlə inkişaf edən seqment PT bazarıdır (hər il $6,7 \%$ artım var). Burada da ən çox gəlir gətirən sahələr şəbəkə üçün PT, kollektiv fəaliyyət üçün nəzərdə tutulmuş PT, kontentlərin ötürülməsi və analitikər üçün vasitələr hesab olunur [13].

$\mathrm{Bu}$ gün PT mühəndisləri tərəfindən İnternet resurslarının pula çevrilməsinin yeni yolları axtarılır. $\mathrm{Bu}$ istiqamətdə əşyaların interneti konsepsiyasının inkişafı ilə resursların pula çevrilməsinin yeni imkanları ortaya çıxır. Buna baxmayaraq bir sıra şirkətlər əşyaların internetinin pula çevrilməsinin hansı yollarla həyata keçiriləcəyini deməyə çətinlik çəkirlər [14]. Müasir dövrümüzdə PT-dən gözlənilən əsas tələblər aşağıdakılardır:

1. Istanilan vaxt va istanilan yerda alyetar olmast. Proqramin istənilən İKT vasitəsində istifadə olunma imkanının olması və onun buludda, lokal şəbəkədə və ya hibrid mühitində yerləşməsi önəmli deyil.

2. İstifadəçi üçün uyğun lisenziyalaşdırma. Lisenziyalaşdırma mexanizmi istifadəçilərin istəyinə uyğun olaraq İKT vasitələrindən asılı olmayaraq dəyişməlidir. Lisenziyanın verilməsi və şərtlərinə riayət olunmasına nəzarət istifadəçilərin avadanlıqlarına və ya onların işlədiyi şirkətlərə deyil, birbaşa özlərinə aid olmalıdır.

3. Istifadəyə nozarat. Proqram məhsulunun faktiki istifadəsinin ödənişinin lisenziya modellərinə getdikcə artan tələbat istehlakçıları PT-dan istifadəni nəzarətdə saxlamaq üçün yeni yollar axtarmağa və biznes-analizi gerçəkləşdirmək üçün yeni vasitələrdən istifadə etməyə məcbur edir.

4. Ümumi istifadəçi təcrübəsi. İstifadəçilərin proqramdan necə istifadə etmələrindən asılı olmayaraq vahid lisenziyalaşdırma forması yaradılmalıdır. Lisenziyalaşdırma prosesi hər iki istiqamət üçün - şəbəkəyə qoşulmuş PT və bulud xidmətlərində eyni olmalıdır.

Müasir dövrdə PT mühəndisləri istifadəçilərin bütün tələblərini qarşılamağa qadir deyillər. Belə nəticəyə gəlmək olar ki, uyğun lisenziyalaşdırma modelləri olmadığından şirkətlər lisenziya tələblərini tam yerinə yetirmirlər. Olbəttə ki, bütün bunlar proqramçıların PT-dən gəlir əldə etmələrinə neqativ təsir göstərir. PT-dən gəlir əldə edilməsi məsələlərinin obyektiv həlli lisenziyalaşdırma modellərinə və çatdırılma metodlarına nəzarətin vahid texnologiyadan idarə olunmasından asılıdır. Bundan əlavə, gəlir əldə etmək üçün bulud texnologiyalarından istifadə edərkən informasiyanın təhlükəsiz saxlanması və emalı üçün PT-nin bütün mümkün imkanları və əlavə mexanizmlərini özündə toplayan vahid lisenziyalaşdırma modeli hazırlanmalıdır.

\section{NӘTİCə}

Araşdırma göstərdi ki, PT bazarında uğur qazanmaq üçün risklər də nəzərə alınmalıdır. PT istehsalçıları yaratdıqları proqram məhsullarının idarə olunma qaydalarını, 
testləşdirilməsi, mövcud və ya sonradan dəyişdirilən funksionallıqlarının izlənməsi də daxil olmaqla lisenziyalaşdırmanın çevik modeli təklifini həll etməlidirlər.

Beləliklə məlum olur ki, ümumi şəkildə PT lisnziyaları ilə əlaqədar əsas problemlərə aşağıdakılar daxildir:

- lisenziyaların idarə olunması və PT-nin yenilənməsinə böyük vəsait tələb olunur;

- lisenziyaların idarə olunması və PT-də yenilənməyə sərf edilən zaman itkisi;

- PT-dən icazəsiz istifadə, piratçılıq;

- PT-nin istehsalı ilə əlaqəsi olmayan digər zaman itkisi və xərclərin olması;

- PT-nın necə istifadə olunmasında biliklərin məhdud olması və $\mathrm{s}$.

Bunları nəzərə alaraq PT sahəsində xidmətlərin keyfiyyətini artırmaq üçün ilk olaraq proqramlardan istifadə şəffaflığını artırmaq, proqram istifadəsinin imkanlarını inkişaf etdirmək, lisenziyanı aktivləşdirmək üçün qiymətləndirmə mexanizmini sadələşdirmək lazımdır. Müasir tələblərə uyğun lisenziyalaşdırma avtomatlaşdırılmış xidmət hesabına real zamanda proqramı idarə etməyə, dəyişməyə və yeniləməyə imkan yaradar. Yeni lisenziyalaşdlrma modeli istifadəçilərin tələblərinə cavab verməklə PT-dən gəlir əldə edilməsi məsələlərinin effektivliyini artırar. PT vasitəsilə gəlir əldə etmək isə təkcə proqramçıların və PT istifadəçilərinin gəlir əldə edilməsinə deyil, həm də ölkənin iqtisadiyyatının inkişafına əhəmiyyətli dərəcədə təsir göstərər.

\section{ӘDӘВIYYAT}

[1]. Д. Харатишвили. Рынок прикладного ПО и его сегментация // КомпьютерПресс, 2008, №1, www.compress.ru/article.aspx?id=18558

[2]. E. Luoma, O. Mazhelis, P. Paakkolanvaara. Software-as-a-Service in the Telecommunication Industry: Problems and Opportunities / Processing of the International Conference of Software Business, 2010, Springer, Berlin, Heidelberg, vol. 51, pp. 138-150.

[3]. Ю. П. Селиванов. Вычислительная техника. Терминология: Справочное пособие. М.: Издательство стандартов, 1989, 168 с.

[4]. H. Ward Classen. A Practical Guide to Software Licensing for Licensees and Licensors. American Bar Association, 2014, 800 p.

[5]. www.righthello.com/software-dev-problems/

[6]. T.H. Kazımov, T.A. Bayramova. Azərbaycanda proqram mühəndisliyinin tədrisinin problemləri // İnformasiya cəmiyyəti problemləri, 2017, №1, 105-111.

[7]. M. Jouvin, J. Harvey, A. Mcnab, E. Sexton-Kennedy, T. Wenaus. Software licence agreements HSF policy guidelines. The Hep Software Foundation, 2016, $10 \mathrm{p}$.

[8]. www.gnu.org/licenses/gpl-3.0.ru.html

[9]. A. Belousov. Problems of Software Market in Ukraine. Computer Crime Research Center, 2004, www.crime-research.org/articles/

[10]. Problems Software Marke Ukraine Виды лицензий на программное обеспечение, www.softholm.com/soft/licence.html

[11]. A. Kundu. Application of Free and Open source software and its Impact on society // Computer Science and Information Technologies, 2010, vol.1, no.4, 226-229.

[12]. Gemalto study reveals software license frustrations. 2015, www.technative.io/gemalto-study-reveals-software-license-frustrations/

[13]. С. Юртайкин. Рынок ПО поможет IT-отрасли вырасти на $14 \%$ через 3 года // 3DNews, 2016, www. 3dnews.ru/928000

[14]. G. Horvat, D. Šoštarić, D. Žagar. Multi-agent Based Software Licensing Model for Embedded Systems / International Symposium on Agent and Multi-Agent Systems: Technologies and Applications, 2012, vol 7327, pp 648-657. 